\title{
Freiheitsstrafe, Deportation
}

und

\section{Unschädlichmachung.}

Ein Wort $z$ ur Verständigung

von

Dr. Reinhard Frank,

Professor der Rechte in Giessen.

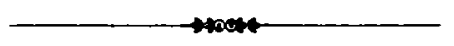

Giessen

J. Ricker'sche Buchhandlung 1895 . 